\title{
sciendo
}

\section{THE RELATIONSHIP BETWEEN SUBCLINICAL KETOSIS AND RUMINAL DYSFUNCTION IN DAIRY COWS}

\author{
Alena Pechová*, Andrea Nečasová \\ University of Veterinary and Pharmaceutical Sciences Brno, \\ Faculty of Veterinary Hygiene and Ecology, Department of Animal Protection, Welfare and Behaviour, \\ Palackého tř. 1-3, Brno, 612 42, Czech Republic \\ •Corresponding author: pechovaa@vfu.cz
}

\begin{abstract}
Ketosis is still an important problem which must be solved in dairy herds. Early precise diagnosis and proper evaluation of the cause of the disease is essential for good management of ketosis on dairy farms. The aim of our work was to analyse the occurrence of rumen dysfunction in connection with subclinical ketosis in dairy herds and to evaluate the relationships between betahydroxybutyrate (BHB) concentration in blood and metabolic parameters in blood, urine and rumen fluid. We analysed the results of metabolic profile tests performed in dairy cattle herds from 1,338 cows. The concentration of BHB significantly correlated with glucose, NEFA (nonesterified fatty acids), bilirubin, AST (aspartate aminotransferase), GGT ( $\gamma$-glutamyl transferase), urea, magnesium and calcium in blood serum and with following parameters of rumen fluid - acetate, propionate, butyrate, acetate/propionate and infusoria. Significant but weak correlations were found between BHB and urine parameters $(\mathrm{pH}$, specific gravity, potassium, magnesium, chloride). Subclinical ruminal acidosis was found in $23.1 \%$ and $16.7 \%$ of dairy cows with light (BHB 1.2-2 $\mathrm{mmol} / \mathrm{L}$ ) and more severe subclinical ketosis (BHB $>2 \mathrm{mmol} / \mathrm{L}$ ) and simple ruminal indigestion in $\mathbf{1 6 . 7 \%}$ and $30 \%$, respectively. On the basis of performed analysis we can conclude that rumen dysfunction is an important factor for the development of ketosis. Veterinary practitioners should suggest checking the feeding management in their diagnostic work with the aim to distinguish primary and secondary ketosis. Only complex and precise diagnostic work allows applying correct and successful therapy not only for individual animals but also for herd health management.
\end{abstract}

Key words: ruminants, dairy cows, ketosis, beta-hydroxybutyrate, rumen dysfunctions

Ketosis is still an important problem which must be solved in dairy herds. The incidence of subclinical ketosis published in literature depends on the limits applied for the ketone bodies and can be found in up to $34 \%$ of the cows in the period from 2 to 7 weeks postpartum (Ingvartsen, 2006). The importance of ketosis is primarily in reduction of milk production, changes in milk composition, disruption of reproductive functions (Abdelli et al., 2017) and increased incidence of production diseases 
(Raboisson et al., 2014). The predominant circulating ketone body in the blood of ruminants is beta-hydroxybutyrate (BHB) and its concentration is considered a gold standard for diagnosing subclinical ketosis (Weng et al., 2015). Subclinical ketosis may start when the level of BHB exceeds $1.0 \mathrm{mmol} / \mathrm{L}$; however, higher values are suggested for first weeks of lactation. Duffield et al. (2009) summarise that increased health risk and reduced milk production appear to start between 1.2 to $1.4 \mathrm{mmol} / \mathrm{L}$ in the first week post-calving and Chapinal et al. (2012) demonstrated that serum BHB levels of 1.4 and $1.2 \mathrm{mmol} / \mathrm{L}$ during the first and second week after calving, respectively, were associated with considerable milk losses. Currently the cut-off value of $1.2 \mathrm{mmol} / \mathrm{L}$ is used to distinguish between cows with and without subclinical ketosis (Bach et al., 2016).

Early precise diagnosis and proper evaluation of the cause of the disease is essential for good management of ketosis on dairy farms. Based on the risk factors for the development of ketosis, Lean et al. (1992) suggested the following classification: primary (production) ketosis, secondary ketosis, butyric acid ketosis and underfeeding ketosis. Primary ketosis occurs 3-6 weeks after calving when the glucose demand exceeds the gluconeogenesis capacity of the liver and low glucose level stimulates the mobilisation of lipids from body reserves. Non-esterified fatty acids are considered an indicator of lipomobilization in blood. Critical thresholds for NEFA have been determined for the prepartum and postpartum periods at $0.3-0.5 \mathrm{mmol} / \mathrm{L}$ and $0.7-1.0 \mathrm{mmol} / \mathrm{l}$, respectively (McArt et al., 2013). The low supply of glucogenic substrates results in increased ketogenesis and thus high concentration of ketone bodies in blood, milk and urine. Secondary ketosis is defined as ketosis resulting from another disease which decreases feed intake. In cows, an increased risk of ketosis has been linked to milk fever, grass tetany, displaced abomasum, retained placenta, uterine infection, foot/leg disorders, mastitis and rumen dysfunction (Ingvartsen, 2006). Nevertheless ketosis can be an outcome or a risk factor for the development of these disorders.

Simple ruminal indigestion and subclinical ruminal acidosis (SARA) are the most important rumen dysfunctions. SARA is traditionally characterised by a low rumen $\mathrm{pH}$ that is below 5.8 for $3-5$ h over a period of $24 \mathrm{~h}$ (Enemark, 2008). However, this definition of SARA is not useful for field cases, because the devices for continuous measurement of ruminal $\mathrm{pH}$ are expensive and are used only in very small number of cows. Thus the field diagnostic of SARA is performed by one-off collection of rumen fluid 3-6 h after morning feeding. Stefanska et al. (2017) evaluated prevalence of subacute ruminal acidosis in Polish dairy herds on the basis of rumenocentesis performed $3-6 \mathrm{~h}$ after morning feeding. They used cut-off value $\mathrm{pH}=5.6-5.8$ for SARA diagnostic. Ruminal fluid collected by oral tube contains higher amounts of saliva and thus $\mathrm{pH}$ value is higher than in samples collected by puncture of the caudoventral ruminal sac. The comparison of these two sampling methods was published by Hofirek and Haas (2001) and they concluded that different reference limits must be used for the evaluation. The reference values assessed for peroral sampling of rumen fluid (Hofírek et al., 2009) are following: pH 6.2-6.8; total acidity 10-30 titr. units; VFA $80-120 \mathrm{mmol} / \mathrm{L}$; acetate $55-65 \mathrm{~mol} \%$; propionate 20-25 mol\%; butyrate 10-17 mol\%. SARA has a negative impact on ruminal fer- 
mentation, low rumen $\mathrm{pH}$ leads to reduced fibre digestion, altered pattern of volatile fatty acid (VFA) production, impaired microbial protein synthesis, altered ruminal microflora and consequently exacerbating of negative energy balance by less efficient digestion (Kleen and Cannizzo, 2012). Moreover SARA is usually reported to depress dry matter intake (DMI) which leads to imbalances in ruminal metabolism by concentrate sorting and insufficient uptake of nutrients (Plaizier et al., 2008). Simple ruminal indigestion could occur mainly in cows that are fed insufficiently and thus the deficiency of glucogenic precursors leads to increased mobilization of body fat, ketogenesis and so called underfeeding ketosis (Danfaer et al., 1995). Butyric acid ketosis is caused by large amounts of butyrate in the feed and probably also by a related depression of feed intake. High concentration of butyric acid is mostly found in wet silages $(\mathrm{DM}<30 \%)$ with inadequate fermentation $(\mathrm{pH}>4.8)$, high contamination with soil (ash $>11 \%$ ) and clostridial fermentation.

From the viewpoint of ketosis etiology, the distinction between the primary and secondary ketosis is very important. Both types of ketosis develop due to energy deficiency and mobilization of lipids, but the therapy and prevention must be different. The main problem is the differentiation between primary ketosis and secondary ketosis which develops due to SARA. In the case of subclinical ruminal acidosis, fluctuating or reduced appetite constitutes the most consistent symptom, whereas other clinical signs may be more inconsistent or weak, thus complicating diagnosis (Owens et al., 1998).

The aim of our work was to analyse the occurrence of rumen dysfunction in relation to the subclinical ketosis in dairy herds and to evaluate the relationships between beta-hydroxybutyrate concentration in blood and metabolic parameters in blood, urine and rumen fluid.

\section{Material and methods}

\section{Animals}

Metabolic profile tests in herds of dairy cows (Czech Fleckvieh, Holstein) in the Czech Republic were performed within routine preventive diagnostic activity. The metabolic profile tests have been performed by the authors during last ten years. None of the animals included in the study showed any clinical signs of diseases. The evaluation of dairy cow metabolism was performed by examination of blood, urine and rumen fluid that were taken from cows in different phases of the reproduction cycle (fresh cows - first 4 weeks after parturition, peak of lactation - 60 to 90 days of lactation, dry period, close up period - up to 2 weeks before parturition).

The evaluation of the relationships between ketosis and rumen function was performed in 1,338 cows (531 fresh cows, 588 cows at the peak of lactation, 219 cows in close up period) from 96 dairy herds.

The concentration of BHB in blood serum of $1.2 \mathrm{mmol} / \mathrm{L}$ was chosen as a decisive parameter for diagnosis of subclinical ketosis (Bach et al., 2016). For more precise interpretation of the relations between ketosis and rumen dysfunction there 
were created four groups according to the concentration of BHB. The first group very low $\mathrm{BHB}(<0.6 \mathrm{mmol} / \mathrm{L})$ included cows with physiological concentration of ketone bodies, the second group - low BHB $(0.6-1.19 \mathrm{mmol} / \mathrm{L})$ included cows with slightly increased level of ketone bodies - compensated state, the third group - mild BHB (1.2-1.99 mmol/L) included cows with subclinical ketosis, and the last group - high $\mathrm{BHB}(\geq 2.0 \mathrm{mmol} / \mathrm{L})$ was represented by cows with high concentration of ketone bodies.

\section{Sampling and analytical procedures}

Samples of blood, urine and rumen fluid were taken 3-6 hours after morning feeding. Blood samples were collected from the vena caudalis mediana into Hemos sampling tubes without any additional anticoagulants for serum examination and with lithium heparin for whole blood examination. A small amount of blood was preserved by sodium fluoride for glucose determination. The following parameters were determined in blood serum: beta-hydroxybutyrate (BHB), nonesterified fatty acids (NEFA), total protein (TP), urea (U), aspartate transaminase EC 2.6.1.1 (AST), gamma-glutamyltransferase EC 2.3.2.2 (GGT), total bilirubin (Bil), calcium, phosphorus, magnesium, copper and zinc. Glucose was measured in fluoride plasma and glutathione peroxidase (GPx) in whole blood.

Urine samples were taken by catheterization or from spontaneous urination. The concentration of minerals ( $\mathrm{Na}, \mathrm{Cl}, \mathrm{K}, \mathrm{Ca}, \mathrm{P}, \mathrm{Mg}$ ), urea, specific gravity and $\mathrm{pH}$ were determined in fresh urine.

Specific gravity was assessed by urinometer and $\mathrm{pH}$ was measured with the use of $\mathrm{pH}$ meter Orion (Thermo Fisher Scientific). The concentration of $\mathrm{Na}, \mathrm{K}, \mathrm{Mg}, \mathrm{Ca}$ in urine and $\mathrm{Ca}, \mathrm{Mg}, \mathrm{Zn}, \mathrm{Cu}$ in blood serum was measured by flame atomic absorption spectrometry on the AAS Solaar M6 (Unicam, Witchford, Cambridgeshire, United Kingdom) device. The concentration of $\mathrm{Zn}$ and $\mathrm{Cu}$ was measured in supernatant after deproteinization of serum samples. Deproteinization was performed by mixing blood serum with 10\% trichloracetic acid in the ratio $1: 1$ and centrifugation after 30 minutes. The other parameters were determined by the automatic analyzer Liasys (AMS, Guidonia, Rome, Italy). Companies providing the reagents for individual parameters analysis are listed as follows: PLIVA Lachema (Brno, Czech Republic) - for urea (Urea UV KIN 4×50, Cat. No. 1307017), total bilirubin (BIL 100, Cat. No. 1105309), $\gamma$-glutamyl transferase (GMT KIN 100, Cat. No. 1302082); DPC Czech (Czech Republic) - reagents for glucose ( ${ }^{\mathrm{G}}$ Glukosa, Cat. No 11601); DIALAB (Praha, Czech Republic) - reagents for phosphorus (Phosphomolybdate test, Cat. No. D00363), chloride (thiocyanate method, test Cat. No. D01223); Randox Laboratories Ltd. (London, United Kingdom) - reagents for nonesterified fatty acids (NEFA, Cat. No. FA 115), beta-hydroxybutyrate (BHB, RANBUT, Cat. No. RB 1007); BioVendor (Brno, Czech Republic) - aspartate aminotransferase (LAST, Cat. No. 10351) and total protein (LProtein total, Cat. No. 12751). All laboratory analyses were performed at the Department of Laboratory Diagnostics for Large Animals (University of Veterinary and Pharmaceutical Sciences Brno).

Rumen fluid was taken with stomach tube $3-6 \mathrm{~h}$ after the morning feeding. We used stomach tube with suction pump developed for the sampling of rumen fluid 
in adult cattle. The tube was removed when it contained at least $250 \mathrm{ml}$ of rumen fluid. Rumen fluid was tested for the presence of saliva contamination by observation of increased viscosity or obvious contamination. Contaminated samples were discarded and a second sample was taken. The samples were preserved for the assessment of $\mathrm{pH}$, total acidity and ammonia by mercury chloride, for the infusoria count by the use of $10 \%$ formaldehyde solution ( $1 \mathrm{ml}$ formaldehyde $+4 \mathrm{ml}$ rumen fluid) and for the measurement of VFA by toluene. The preserved samples of rumen fluid were transported to the laboratory, samples for the assessment of VFA were frozen $\left(-20^{\circ} \mathrm{C}\right)$ until the measurement $(1-2$ weeks) and samples for the assessment of total acidity, $\mathrm{pH}$ and infusoria count were cooled $\left(5-8^{\circ} \mathrm{C}\right)$ and measured next day after the collection. Total acidity was established by titration method. Ten millilitres of sample was titrated with $0.1 \mathrm{M}$ sodium hydroxide with $\mathrm{pH} 8.5$ as the endpoint using a $\mathrm{pH}$ meter. The amount of sodium hydroxide was proportional to the total acidity value. The $\mathrm{pH}$ level was measured by the $\mathrm{pH}$ Meter Lab 850 (SCHOTT Instruments $\mathrm{GmbH}$, Mainz, Germany). Infusoria count was done with the use of a microscope in a Fuchs-Rosenthal Counting Chamber (Hausser Scientific Co., Horsham, USA) by dilution 1 : 20 and staining $0.1 \%$ methylene blue. Concentrations of individual VFA (acetate, propionate, butyrate, valerate) in the rumen fluid were determined by gas chromatography using an Agilent 6820 GC System (Agilent Technologies, USA). The ammonia concentration was determined by Berthelot's photometric reaction.

\section{Statistical analysis}

The basic statistical parameters for all variables were calculated and are shown in tables. The normality of the data distribution was assessed using KolmogorovSmirnov test. The data on BHB concentration in blood serum was not normally distributed. The relations between concentration of BHB in serum and other examined parameters were evaluated by regression analysis and Spearman's correlation coefficient is shown. The difference between the four groups according to BHB concentration was tested by one-way ANOVA and Tukey-HSD post hoc test. The significance level was set at $\mathrm{P}<0.05$. The statistical analysis was performed by UNISTAT Version 6.0 (Unistat Ltd, England)

\section{Results}

The occurrence of subclinical ketosis in our set of data from Czech dairy herds on the basis of the concentration of beta-hydroxybutyrate in blood is shown in Table 1. Increased concentration of BHB $(\geq 1.2 \mathrm{mmol} / \mathrm{L})$ was found in $8.1 \%$ of all investigated cows. The highest occurrence of subclinical ketosis was in fresh cows $(14.5 \%)$, lower in cows at the peak of lactation (4.3\%) and the lowest in close up period $(2.7 \%)$. 
Table 1 . The occurrence of subclinical ketosis in dairy cows in different phases of lactation

\begin{tabular}{l|c|c|c|c}
\hline & \multicolumn{4}{|c}{ Beta-hydroxybutyrate (mmol/L) } \\
\cline { 2 - 5 } & $<0.6$ & $0.6-1.19$ & $1.2-2.0$ & $>2.0$ \\
\hline Fresh cows ( $\mathrm{n}=531)$ & $42.2 \%$ & $43.3 \%$ & $10.0 \%$ & $4.5 \%$ \\
Peak of lactation $(\mathrm{n}=588)$ & $46.1 \%$ & $49.7 \%$ & $3.6 \%$ & $0.7 \%$ \\
Close up period (n=219) & $67.6 \%$ & $29.7 \%$ & $1.8 \%$ & $0.9 \%$ \\
Together ( $\mathrm{n}=1338)$ & $48.1 \%$ & $43.9 \%$ & $5.8 \%$ & $2.2 \%$ \\
\hline
\end{tabular}

\section{Blood}

The basic statistical characteristics of evaluated blood parameters are shown in Table 2. This table also shows correlation coefficients of beta-hydroxybutyrate in blood serum with other evaluated parameters in complete data set and in the cows with subclinical ketosis (BHB $\geq 1.2 \mathrm{mmol} / \mathrm{L})$. Significant correlations in complete data set were found between BHB and glucose, NEFA, bilirubin, AST, GGT, urea, $\mathrm{Mg}$ and $\mathrm{Ca}$ in blood serum; however most of them were very weak. The correlation coefficient between evaluated variables and BHB concentration in cows with subclinical ketosis was higher for some parameters and shows closer relationships (glucose, NEFA, total bilirubin, AST).

Table 2. The basic statistical characteristics of selected blood parameters evaluated in the complete data set and the Spearman correlation coefficient of individual parameters with BHB concentration in serum of all cows $(n=1338)$ and cows with subclinical ketosis $(n=108)$

\begin{tabular}{lcc|c|c|c|c|c}
\hline & Mean & Median & $\begin{array}{c}\text { Standard } \\
\text { deviation }\end{array}$ & Min. & Max. & \multicolumn{2}{|c|}{ Correlation coefficient } \\
\cline { 6 - 9 } & & & & & complete & BHB $\geq 1.2$ mmol/L \\
\hline BHB $(\mathrm{mmol} / \mathrm{L})$ & 0.72 & 0.61 & 0.49 & 0.03 & 5.81 & & \\
Protein $(\mathrm{g} / \mathrm{L})$ & 73.8 & 73.3 & 7.62 & 50.9 & 110.3 & -0.015 & -0.088 \\
Glucose $(\mathrm{mmol} / \mathrm{L})$ & 3.33 & 3.31 & 0.48 & 1.43 & 5.87 & $-0.336^{*}$ & $-0.374^{*}$ \\
Urea $(\mathrm{mmol} / \mathrm{L})$ & 5.12 & 5.00 & 1.50 & 1.68 & 10.5 & $0.066^{*}$ & -0.053 \\
Bilirubin $(\mu \mathrm{mol} / \mathrm{L})$ & 5.08 & 4.40 & 3.87 & 0.10 & 55.2 & $0.141^{*}$ & $0.336^{*}$ \\
AST $(\mu \mathrm{kat} / \mathrm{L})$ & 1.72 & 1.54 & 0.74 & 0.07 & 7.12 & $0.090^{*}$ & $0.4483^{*}$ \\
GGT $(\mu \mathrm{kat} / \mathrm{L})$ & 0.47 & 0.42 & 0.23 & 0.01 & 2.95 & $0.075^{*}$ & 0.188 \\
NEFA $(\mu \mathrm{mol} / \mathrm{L})$ & 0.55 & 0.42 & 0.43 & 0.03 & 3.90 & $0.386^{*}$ & $0.383^{*}$ \\
Calcium $(\mathrm{mmol} / \mathrm{L})$ & 2.30 & 2.30 & 0.19 & 1.59 & 2.93 & $-0.049^{*}$ & $-0.469^{*}$ \\
Phosphorus & 1.90 & 1.87 & 0.36 & 0.97 & 4.05 & -0.022 & $-0.199^{*}$ \\
$(\mathrm{mmol} / \mathrm{L})$ & & & & & & & \\
Zinc $(\mu \mathrm{mol} / \mathrm{L})$ & 15.0 & 14.9 & 2.76 & 7.22 & 25.0 & -0.007 & -0.115 \\
Copper $(\mu \mathrm{mol} / \mathrm{L})$ & 12.6 & 12.6 & 2.36 & 6.49 & 23.8 & $0.049^{*}$ & 0.137 \\
Magnesium $(\mathrm{mmol} / \mathrm{L})$ & 1.01 & 1.01 & 0.13 & 0.50 & 1.85 & $-0.094^{*}$ & $-0.164^{*}$ \\
GPx $(\mu \mathrm{kat} / \mathrm{L})$ & 708 & 719 & 178 & 129 & 1329 & -0.009 & 0.043 \\
\hline
\end{tabular}

$* \mathrm{P} \leq 0.05$. 
Significant relations were found between serum $\mathrm{Ca}, \mathrm{P}, \mathrm{Mg}$ and $\mathrm{BHB}$. These correlations were negative, which means that cows with ketosis had lower concentrations of these macroelements in blood. The highest correlation coefficient was found between calcium and BHB $(\mathrm{r}=-0.469)$. The levels of microelements $(\mathrm{Zn}, \mathrm{Cu})$ and GPx did not show relations to ketosis.

\section{Urine}

The basic statistical characteristics of evaluated urine parameters and correlation coefficients are shown in Table 3 . We found significant but only weak correlations between $\mathrm{BHB}$ and urine parameters $(\mathrm{pH}$, specific gravity, potassium, magnesium, chloride). Similarly to data obtained from blood we found closer relations between $\mathrm{BHB}$ and urine parameters in ketotic cows than in complete data set. Significant negative correlation was found between $\mathrm{BHB}$ and urine $\mathrm{pH}$, which corresponds with increased amounts of acids in the body. The relations to macroelements differ, negative correlations were found between $\mathrm{BHB}$, potassium and chlorides probably due to decreased feed intake; however positive correlation was found between BHB and calcium.

Table 3. The basic statistical characteristics of selected urine parameters of the complete data set and the Spearman correlation coefficient of individual parameters with BHB concentration in serum of all cows $(n=1338)$ and cows with subclinical ketosis $(n=108)$

\begin{tabular}{|c|c|c|c|c|c|c|c|}
\hline & \multirow{2}{*}{ Mean } & \multirow{2}{*}{ Median } & \multirow{2}{*}{$\begin{array}{l}\text { Standard } \\
\text { deviation }\end{array}$} & \multirow{2}{*}{ Min. } & \multirow{2}{*}{ Max. } & \multicolumn{2}{|c|}{ Correlation coefficient with BHB } \\
\hline & & & & & & complete & $\mathrm{BHB} \geq 1.2 \mathrm{mmol} / \mathrm{L}$ \\
\hline $\mathrm{pH}$ & 8.27 & 8.32 & 0.27 & 6.23 & 8.84 & $-0.052 *$ & $-0.291^{*}$ \\
\hline $\begin{array}{l}\text { Specific gravity } \\
(\mathrm{g} / \mathrm{L})\end{array}$ & 1030 & 1031 & 8.31 & 1000 & 1058 & $-0.090^{*}$ & -0.115 \\
\hline $\begin{array}{l}\text { Urea } \\
(\mathrm{mmol} / \mathrm{L})\end{array}$ & 210 & 208 & 89.6 & 19.6 & 559 & -0.024 & 0.180 \\
\hline $\begin{array}{l}\text { Sodium } \\
(\mathrm{mmol} / \mathrm{L})\end{array}$ & 82.6 & 78.0 & 59.4 & 0.50 & 366 & -0.029 & -0.133 \\
\hline $\begin{array}{l}\text { Potassium } \\
(\mathrm{mmol} / \mathrm{L})\end{array}$ & 214 & 209 & 84.5 & 22.4 & 528 & $-0.077^{*}$ & $-0.298^{*}$ \\
\hline $\begin{array}{l}\text { Calcium } \\
(\mathrm{mmol} / \mathrm{L})\end{array}$ & 0.90 & 0.30 & 1.53 & 0.01 & 15.0 & 0.045 & $0.251^{*}$ \\
\hline $\begin{array}{l}\text { Magnesium } \\
(\mathrm{mmol} / \mathrm{L})\end{array}$ & 17.2 & 15.8 & 10.4 & 0.15 & 73.6 & $-0.118^{*}$ & 0.021 \\
\hline $\begin{array}{l}\text { Phosphorus } \\
(\mathrm{mmol} / \mathrm{L})\end{array}$ & 2.12 & 1.50 & 2.44 & 0.01 & 25.8 & -0.003 & 0.021 \\
\hline $\begin{array}{l}\text { Chloride } \\
(\mathrm{mmol} / \mathrm{L})\end{array}$ & 41.8 & 32.1 & 33.1 & 0.80 & 234 & $-0.124 *$ & $-0.239^{*}$ \\
\hline
\end{tabular}

$* \mathrm{P} \leq 0.05$.

\section{Rumen fluid}

The next topic of our work was the evaluation of rumen fermentation during subclinical ketosis with the aim to differentiate primary (production) ketosis and se- 
condary ketosis which can arise due to subclinical ruminal acidosis and consequently decreased feed intake. The basic statistical characteristics of evaluated rumen fluid parameters and correlation coefficients with blood serum BHB are shown in Table 4. Significant correlations (complete data set) were found between BHB and acetate, propionate, butyrate, ratio acetate/propionate and infusoria count.

Table 4. The basic statistical characteristics of selected rumen fluid parameters of the complete data set and the Spearman correlation coefficient of individual parameters with BHB concentration in serum of all cows $(\mathrm{n}=1338)$ and cows with subclinical ketosis $(\mathrm{n}=108)$

\begin{tabular}{|c|c|c|c|c|c|c|c|}
\hline & \multirow{2}{*}{ Mean } & \multirow{2}{*}{ Median } & \multirow{2}{*}{$\begin{array}{l}\text { Standard } \\
\text { deviation }\end{array}$} & \multirow{2}{*}{ Min. } & \multirow{2}{*}{ Max. } & \multicolumn{2}{|c|}{ Correlation coefficient with BHB } \\
\hline & & & & & & complete & $\mathrm{BHB} \geq 1.2 \mathrm{mmol} / \mathrm{L}$ \\
\hline $\mathrm{pH}$ & 6.50 & 6.51 & 0.37 & 5.29 & 7.76 & -0.031 & 0.0968 \\
\hline $\begin{array}{l}\text { Total acidity } \\
\text { (titr. unit) }\end{array}$ & 23.9 & 22.6 & 8.33 & 4.13 & 67.8 & -0.003 & -0.156 \\
\hline $\begin{array}{l}\text { Infusoria } \\
\left(10^{3} / \mathrm{ml}\right)\end{array}$ & 272 & 232 & 181 & 6.0 & 1680 & $0.057 *$ & $-0.212^{*}$ \\
\hline $\begin{array}{l}\text { Ammonia } \\
(\mathrm{mmol} / \mathrm{L})\end{array}$ & 6.83 & 6.15 & 3.90 & 0.22 & 24.2 & 0.033 & 0.111 \\
\hline $\begin{array}{l}\text { VFA } \\
(\mathrm{mmol} / \mathrm{L})\end{array}$ & 106 & 106 & 20.9 & 32.2 & 162 & -0.031 & $-0.334 *$ \\
\hline $\begin{array}{l}\text { Acetate } \\
(\mathrm{mol} \%)\end{array}$ & 61.2 & 61.4 & 4.81 & 43.6 & 80.3 & $0.125^{*}$ & 0.125 \\
\hline $\begin{array}{l}\text { Propionate } \\
(\mathrm{mol} \%)\end{array}$ & 22.6 & 21.6 & 4.38 & 12.0 & 39.1 & $-0.271^{*}$ & -0.128 \\
\hline $\begin{array}{l}\text { Butyrate } \\
(\mathrm{mol} \%)\end{array}$ & 13.0 & 12.6 & 2.53 & 5.40 & 26.7 & $0.279^{*}$ & -0.026 \\
\hline $\begin{array}{l}\text { Valerate } \\
(\mathrm{mol} \%)\end{array}$ & 3.25 & 3.10 & 1.07 & 0.70 & 8.20 & 0.041 & -0.143 \\
\hline Acetate/Propionate & 2.84 & 2.84 & 0.73 & 1.18 & 6.42 & $0.231^{*}$ & -0.151 \\
\hline
\end{tabular}

$* \mathrm{P} \leq 0.05$.

The values of rumen fluid parameters in cows according to serum BHB category are shown in Table 5. Statistically significant differences between individual groups were found only in the concentration of volatile fatty acids (total, acetate, propionate, butyrate). The cows with ketosis had a lower concentration of VFA, mol\% of propionate, butyrate and contrary higher mol\% of acetate. These changes are typical for decreased efficiency of rumen fermentation due to lower amounts of starch and higher proportion of fibre in the diet. However the mean value of rumen $\mathrm{pH}$ was not influenced by the occurrence of ketosis in cows. We found similar range of rumen $\mathrm{pH}$ value in all four groups of cows. Subclinical ruminal acidosis $(\mathrm{pH}<6.2)$ was diagnosed in 266 cows (19.9\% of the whole data set) and simple ruminal indigestion ( $\mathrm{pH}>6.8)$ in 273 cows $(20.4 \%$ of the whole data set). Similar occurrence of rumen dysfunction was found also in cows with ketosis (BHB $\geq 1.2 \mathrm{mmol} / \mathrm{L} ; \mathrm{n}=108$ ); 
subclinical ruminal acidosis was found in $21.3 \%$ and simple ruminal indigestion in $20.4 \%$ of cows.

Table 5. The values of selected rumen fluid parameters (mean \pm standard deviation) in cows according to serum BHB category $(\mathrm{BHB}<0.6: \mathrm{n}=643$; $\mathrm{BHB}=0.6-1.19: \mathrm{n}=587 ; \mathrm{BHB}=1.2-2.0: \mathrm{n}=78$; $\mathrm{BHB}$

\begin{tabular}{|c|c|c|c|c|c|}
\hline \multicolumn{6}{|c|}{$>2.0: \mathrm{n}=30)$} \\
\hline & \multicolumn{4}{|c|}{$\mathrm{BHB}(\mathrm{mmol} / \mathrm{L})$} & \multirow{2}{*}{$\begin{array}{c}\text { P-value } \\
\text { (ANOVA) }\end{array}$} \\
\hline & $<0.6$ & $0.6-1.19$ & $1.2-2.0$ & $>2.0$ & \\
\hline $\mathrm{pH}$ & $6.51 \pm 0.39$ & $6.49 \pm 0.34$ & $6.50 \pm 0.35$ & $6.57 \pm 0.42$ & 0.537 \\
\hline $\begin{array}{l}\text { Total acidity } \\
\text { (titr. unit) }\end{array}$ & $23.9 \pm 8.36$ & $24.1 \pm 8.28$ & $23.6 \pm 8.44$ & $21.1 \pm 8.49$ & 0.313 \\
\hline $\begin{array}{l}\text { Infusoria } \\
\left(10^{3} / \mathrm{ml}\right)\end{array}$ & $265 \pm 178$ & $273 \pm 182$ & $304 \pm 213$ & $246 \pm 149$ & 0.099 \\
\hline $\begin{array}{l}\text { Ammonia } \\
(\mathrm{mmol} / \mathrm{L})\end{array}$ & $6.64 \pm 3.50$ & $6.92 \pm 4.12$ & $7.13 \pm 4.88$ & $7.86 \pm 4.65$ & 0.196 \\
\hline $\begin{array}{l}\text { VFA } \\
(\mathrm{mmol} / \mathrm{L})\end{array}$ & $106 \pm 21.5 \mathrm{a}$ & $107 \pm 19.6 \mathrm{~b}$ & $103 \pm 20.2 \mathrm{c}$ & $87.9 \pm 25.1 \mathrm{a}, \mathrm{b}, \mathrm{c}$ & 0.003 \\
\hline $\begin{array}{l}\text { Acetate } \\
(\mathrm{mol} \%)\end{array}$ & $60.7 \pm 5.3 \mathrm{a}, \mathrm{b}$ & $61.4 \pm 4.3 \mathrm{c}$ & $62.2 \pm 3.7 \mathrm{a}$ & $63.9 \pm 5.5 \mathrm{~b}, \mathrm{c}$ & $<0.001$ \\
\hline $\begin{array}{l}\text { Propionate } \\
(\mathrm{mol} \%)\end{array}$ & $23.8 \pm 4.9 \mathrm{a}, \mathrm{b}, \mathrm{c}$ & $21.9 \pm 3.5 \mathrm{a}, \mathrm{d}, \mathrm{e}$ & $20.7 \pm 2.7 \mathrm{~b}, \mathrm{~d}$ & $19.6 \pm 2.7 \mathrm{c}, \mathrm{e}$ & $<0.001$ \\
\hline $\begin{array}{l}\text { Butyrate } \\
(\mathrm{mol} \%)\end{array}$ & $12.4 \pm 2.3 \mathrm{a}, \mathrm{b}, \mathrm{c}$ & $13.4 \pm 2.5 \mathrm{a}$ & $13.6 \pm 2.8 \mathrm{~b}$ & $13.8 \pm 3.9 \mathrm{c}$ & $<0.001$ \\
\hline $\begin{array}{l}\text { Valerate } \\
(\mathrm{mol} \%)\end{array}$ & $3.21 \pm 1.06$ & $3.27 \pm 1.07$ & $3.38 \pm 1.14$ & $2.95 \pm 1.16$ & 0.143 \\
\hline Acetate/Propionate & $2.71 \pm 0.80 \mathrm{a}, \mathrm{b}, \mathrm{c}$ & $2.91 \pm 0.63 \mathrm{a}, \mathrm{d}$ & $3.07 \pm 0.52 \mathrm{~b}$ & $3.35 \pm 0.78 \mathrm{c}, \mathrm{d}$ & $<0.001$ \\
\hline $\begin{array}{l}\text { Acetate } \\
(\mathrm{mmol} / \mathrm{L})\end{array}$ & $63.9 \pm 11.2 \mathrm{a}$ & $65.2 \pm 10.9 \mathrm{~b}$ & $63.9 \pm 11.2 \mathrm{c}$ & $55.1 \pm 15.5 \mathrm{a}, \mathrm{b}, \mathrm{c}$ & $<0.001$ \\
\hline $\begin{array}{l}\text { Propionate } \\
(\mathrm{mmol} / \mathrm{L})\end{array}$ & $25.8 \pm 8.9 \mathrm{a}, \mathrm{b}, \mathrm{c}$ & $23.6 \pm 6.7 \mathrm{a}, \mathrm{d}, \mathrm{e}$ & $21.6 \pm 5.8 \mathrm{~b}, \mathrm{~d}, \mathrm{f}$ & $17.3 \pm 5.6 \mathrm{c}, \mathrm{e}, \mathrm{f}$ & $<0.001$ \\
\hline $\begin{array}{l}\text { Butyrate } \\
(\mathrm{mmol} / \mathrm{L})\end{array}$ & $13.2 \pm 3.8 \mathrm{a}, \mathrm{b}$ & $14.4 \pm 4.0 \mathrm{a}, \mathrm{c}$ & $14.4 \pm 4.7 \mathrm{~b}$ & $12.3 \pm 5.3 \mathrm{c}$ & $<0.001$ \\
\hline $\begin{array}{l}\text { Valerate } \\
(\mathrm{mmol} / \mathrm{L})\end{array}$ & $3.48 \pm 1.42 \mathrm{a}$ & $3.54 \pm 1.42 \mathrm{~b}$ & $3.54 \pm 1.34 \mathrm{c}$ & $2.66 \pm 1.36 \mathrm{a}, \mathrm{b}, \mathrm{c}$ & 0.015 \\
\hline
\end{tabular}

$\mathrm{a}, \mathrm{b}, \mathrm{c}, \mathrm{d}, \mathrm{e}, \mathrm{f}-\mathrm{P} \leq 0.05$ the same letters in one row show statistically significant difference between groups (Tukey-HSD test).

The distribution of the data which characterises rumen fermentation according to the serum BHB category is shown in graphs 1-10. Subclinical ruminal acidosis and simple ruminal indigestion were found in $22.1 \%$ and $24.1 \%$ of cows with very low BHB, $17.2 \%$ and $16.4 \%$ of cows with low BHB, $23.1 \%$ and $16.7 \%$ of cows with mild $\mathrm{BHB}, 16.7 \%$ and $30 \%$ of cows with high $\mathrm{BHB}$, respectively. 
Rumen juice - $\mathrm{pH}$

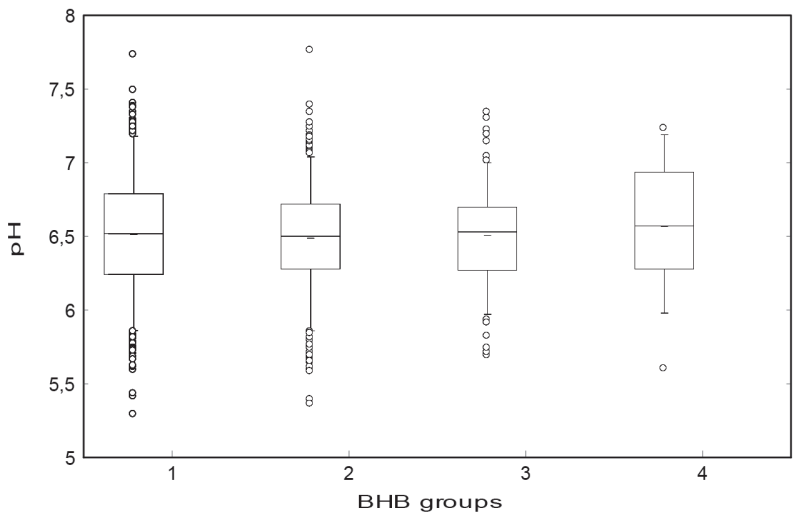

Total acidity

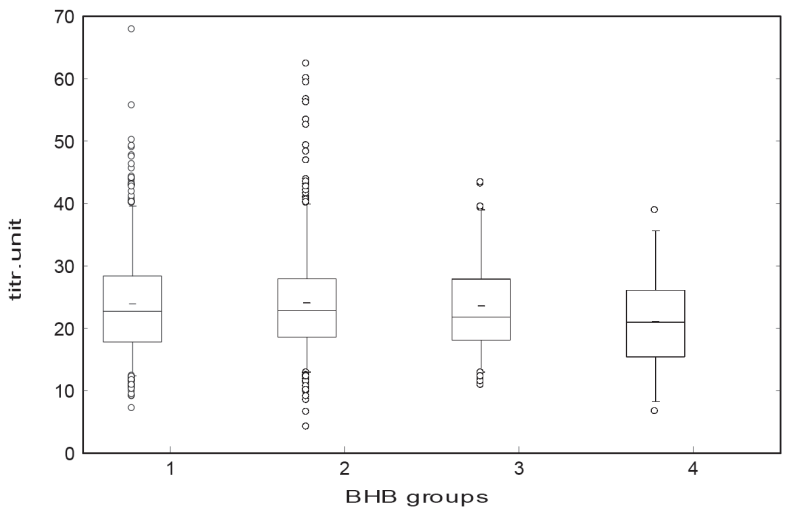

Infusoria

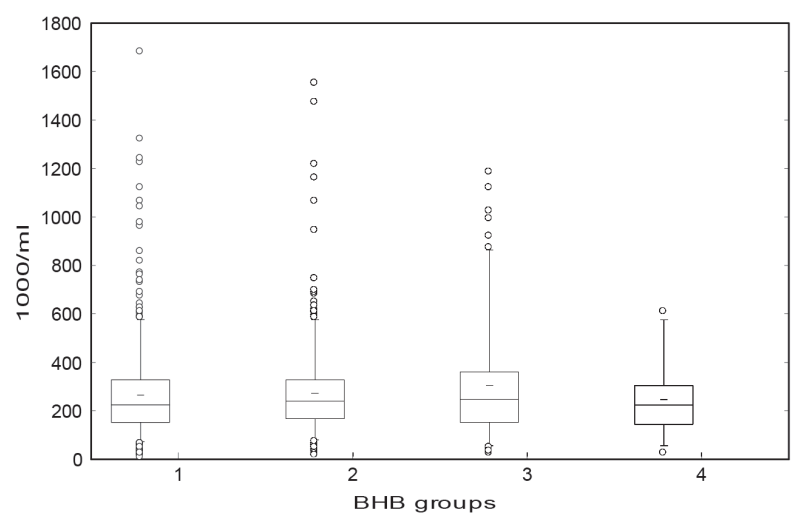


Ammonia

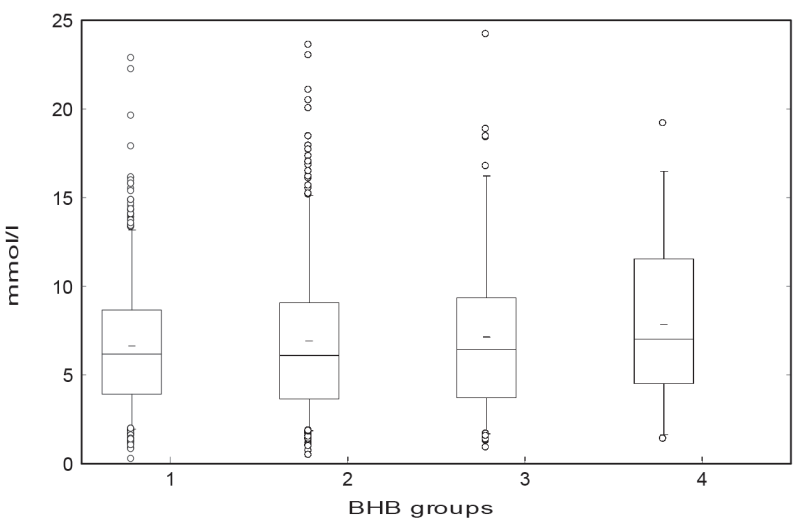

Volatile fatty acid

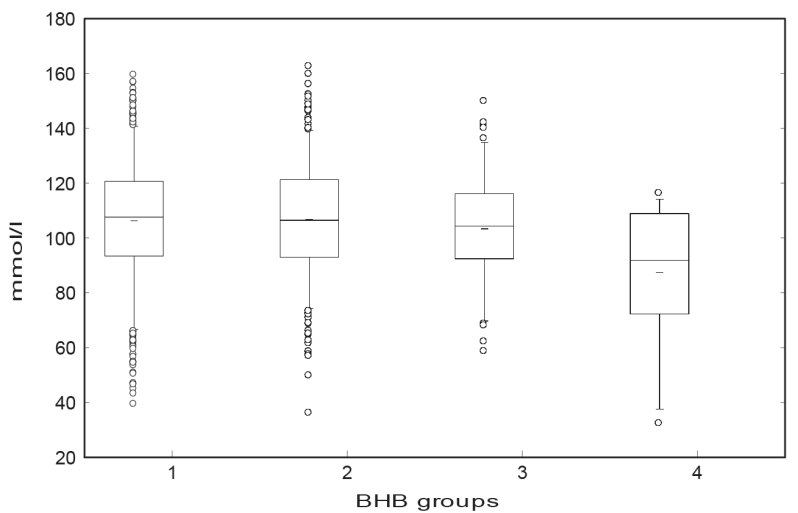

Acetate

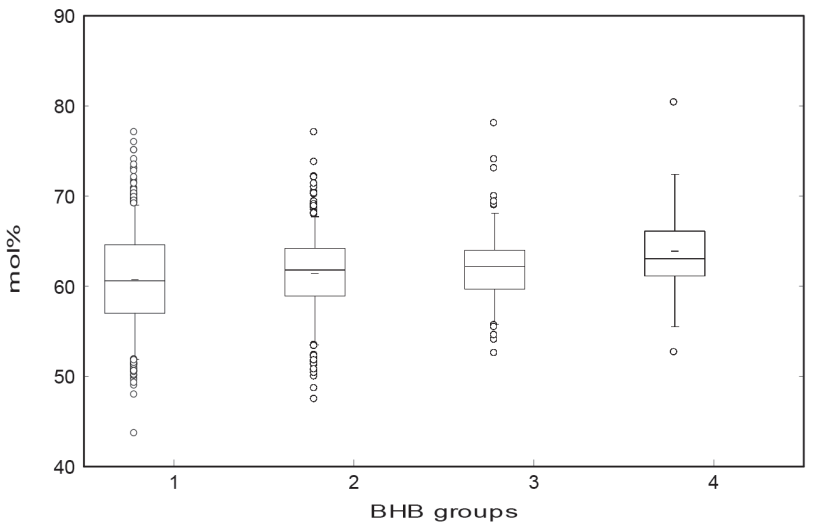


Propionate

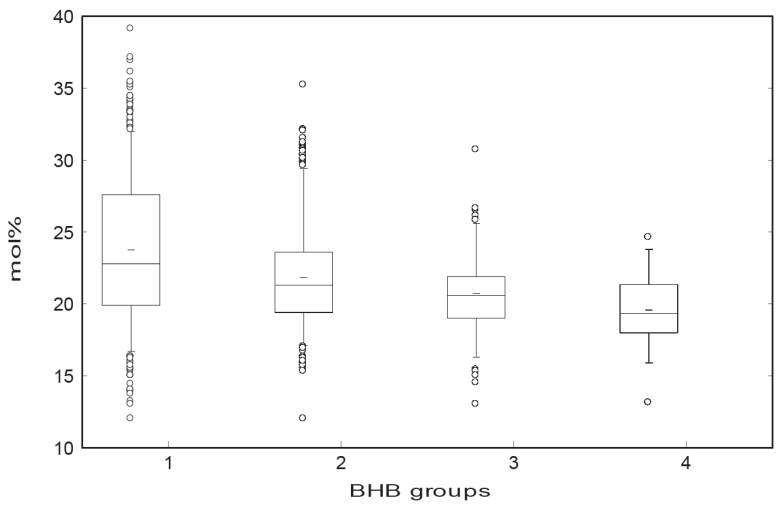

Butyrate

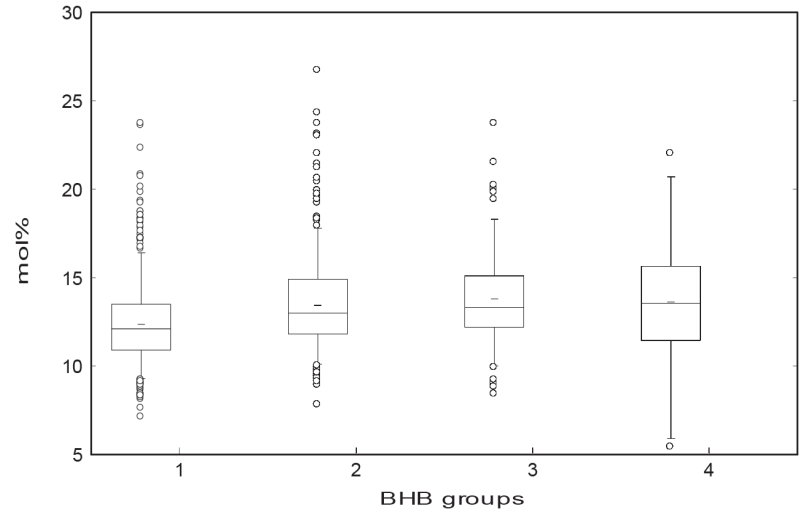

Valerate

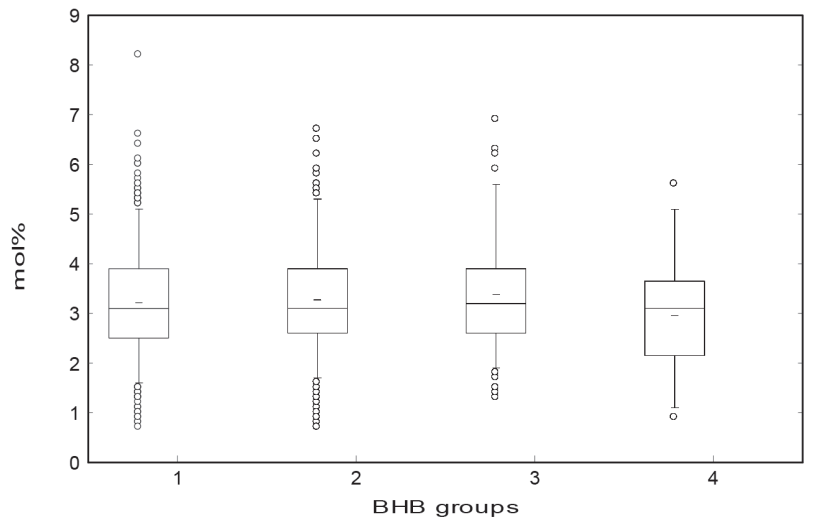


Acetate/Propionate

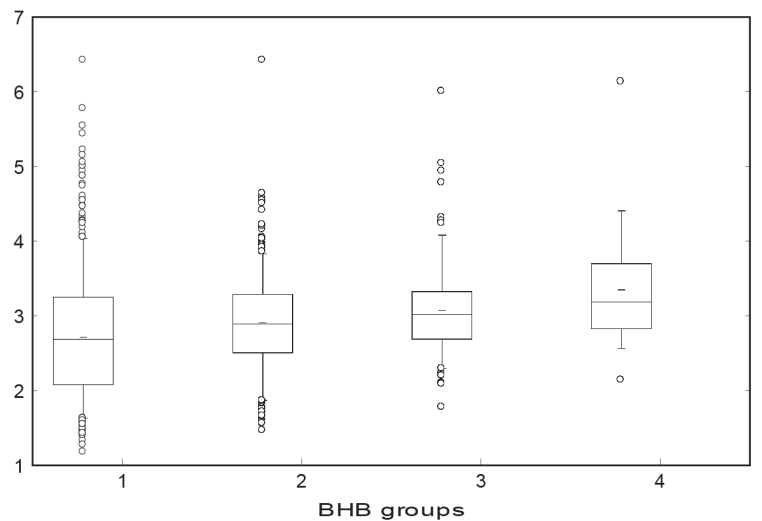

Graph 1-10: The distribution of the selected rumen fluid parameters according to serum BHB category $(\mathrm{BHB}<0.6: \mathrm{n}=643$; $\mathrm{BHB}=0.6-1.19: \mathrm{n}=587$; $\mathrm{BHB}=$ $1.2-2.0: \mathrm{n}=78$; $\mathrm{BHB}>2.0: \mathrm{n}=30$ ). Boxes and whiskers plot include $25-75 \%$ interval, horizontal lines within boxes indicate medians, short lines within boxes indicate means, vertical lines are $95 \%$ and circles extreme values.

\section{Discussion}

The relations between BHB level and other metabolic parameters are rarely evaluated in available literature. The highest negative correlation coefficient was found between BHB and glucose; positive correlations were found between BHB and NEFA, total bilirubin and AST which correspond to the pathogenesis of ketosis. Cows with high milk production use glucose mainly for lactose synthesis and high energy demands must be covered by lipolysis which provides precursors to yield energy in the form of ATP. The liver is the most active metabolic organ for cows to metabolise NEFA via 3 pathways: complete oxidation producing ATP, $\mathrm{CO}_{2}, \mathrm{H}_{2} \mathrm{O}$; incomplete oxidation producing ketone bodies; reesterification to triacylglycerols. When the uptake of NEFA exceeds the oxidation ability of the liver, triacylglycerols are stored in the liver thereby leading to liver steatosis. The correlation coefficient between BHB and NEFA in our work was similar to the values published by Ruoff et al. (2016) who found 0.29 and 0.44 two and ten days after calving, respectively. McCarthy et al. (2015) found weak relationships between blood concentrations of NEFA and BHB during the periparturient period (correlation coefficients 0.07 and 0.26 during 3 weeks prepartum and postpartum, respectively).

The significant relations between BHB, AST and total bilirubin show close relations between ketosis and liver steatosis which develops in dairy cows when the amount of NEFA released from adipose tissue exceeds the oxidation capacity of the liver. Li et al. (2012) found the changes of enzyme concentrations in the hepatocytes 
showing that fatty acid beta-oxidation capability is altered in the liver of ketotic compared with nonketotic cows. They reported higher protein levels of acyl-CoA synthetase, but in contrast lower carnitine palmatoyltransferase I, II, acyl-CoA dehydrogenase, 3-hydroxy-3-methylglutaryl-CoA synthase and acetyl-CoA dehydrogenase. They concluded that high serum NEFA and BHB concentrations play key roles in affecting pathways of fatty acid metabolism in the liver. Our findings regarding relations between BHB, AST and bilirubin but not between BHB and GGT are consistent with the recommendation for diagnosis of liver steatosis (Bobe et al., 2004; Pechová et al., 2002). In dairy cows with high and low lipomobilization González et al. (2010) found significant negative correlations only between BHB and glucose, while other evaluated parameters (NEFA, total protein, albumin, globulins, urea, calcium, phosphorus, AST) did not correlate significantly with BHB. Tothova et al. (2014) demonstrated that metabolic changes associated with energy imbalance may be related to alterations in protein metabolism shortly after calving. They found significant negative correlations between $\mathrm{BHB}$ and total protein or immunoglobulin $\mathrm{G}$ and positive correlations between $\mathrm{BHB}$ and acute phase proteins (haptoglobin, serum amyloid A). Contrary to this work we did not find any relations between total protein and BHB. The reason is probably that the concentration of total protein in blood serum is influenced by many factors such as inflammation, infection, liver and kidney function, daily ration, etc.

Important findings in our work are the relations between ketosis and macromineral metabolism, mainly negative correlation between BHB and calcium. Hypocalcaemia reduces the ability of immune cells to respond to stimuli (Kimura et al., 2006), thus contributing to infections, such as mastitis or metritis. Moreover calcium deficiency reduces smooth muscle contraction and thus prevents efficient teat closure, which contributes to mastitis. Its effect on muscle contraction also results in reduced rumen and abomasal motility leading to displaced abomasum and reduced feed intake (Goff, 2008). The relation between energy metabolism and calcium was found by Reinhardt et al. (2011), who reported higher lipomobilization in cows with subclinical hypocalcaemia after parturition. Hypocalcaemia could be one of the factors which add to the development of ketosis. The cause can be liver steatosis which often occurs during ketosis. Although cholecalciferol can be obtained from the diet or from biosynthesis in the skin, calcitriol formation (the active form) requires a 25-hydroxylation in the liver and a 1-hydroxylation in the kidney. Liver and/or kidney disease can result in a $1,25(\mathrm{OH})_{2}-\mathrm{D}_{3}$ deficiency. Associations between microminerals and ketosis were not detected in our work. On the contrary Zhang et al. (2010) found lower concentration of zinc in the blood serum of subclinically ketotic dairy cows in comparison with healthy cows. These authors hypothesised that insufficient Zn may influence the synthesis and metabolism of BHB by affecting the secretion of insulin in dairy cows with subclinical ketosis; however our data did not support this hypothesis.

The relations between ketosis and ruminal dysfunction are more complicated. We found significant correlations (complete data set) between BHB and proportion of individual volatile fatty acids (VFA). The negative correlation with propionate is consistent with the pathogenesis of ketosis, since of the VFA only propionate is 
glucogenic. Significant correlation was found also with butyrate, which shows that butyrate production in the rumen can influence to some extent the BHB concentration in blood. Nevertheless in ketotic cows the relations between butyrate and $\mathrm{BHB}$ was not significant. The reason for this is probably that ketosis which we diagnosed was mostly of different etiology than high intake of butyrate from silages or its increased production in the rumen. Butyrate produced in the rumen is converted to BHB during the passage across the ruminal and omasal walls. The importance of butyrate produced in the rumen for ketogenesis was confirmed by Doreau et al. (2001).

Group of cows with subclinical ketosis has shown significant relations between $\mathrm{BHB}$ and total production of volatile fatty acids, which was lower in cows with high concentration of BHB in blood. The relations between BHB and other evaluated parameters were not significant in ketotic cows. This could be explained by the fact that we found similar number of ketotic cows with simple ruminal indigestion and subacute ruminal acidosis. Simple ruminal indigestion is characterised by decreased intensity of rumen fermentation with low production of VFA and slightly increased $\mathrm{pH}$. The cause of ruminal indigestion can be decreased feed intake due to different reasons (foot/leg disorders, infection diseases, toxaemia, ketosis) or low quality of the feed ration (low concentration of main nutrients, high content of inhibitory substances). Most common rumen dysfunction during ketosis is simple indigestion, which develops due to low quality of the ration and later due to decreased feed intake. The occurrence of chronic/subacute ruminal acidosis (SARA) shows different etiology of ketosis. In these SARA cows the energy deficiency develops due to reduced DMI. The decrease in DMI is often presented as a consistent sign and sensitive indicator of SARA (Abdela, 2016). Enemark and Jorgensen (2001) published results of a questionnaire survey conducted among Danish dairy practitioners to investigate reduced appetite and its relation to subclinical ruminal acidosis in postpartum dairy cows. The most common diagnoses believed to occur were ketosis $(26 \%)$, ruminal acidosis $(22 \%)$, abomasal disorders $(16 \%)$, subclinical hypocalcaemia $(15 \%)$ and milk fever (15\%); however this study did not evaluate the relations between ketosis and rumen acidosis.

The clinical picture of rumen digestion during secondary ketosis developing due to subclinical ruminal acidosis is changing over time. Ruminal acidosis is present in the early stage of the disease, however after some time due to decreased feed intake and thus decreased amounts of substrates for microbial digestion, the intensity of rumen fermentation is reduced and ruminal indigestion develops. The precise diagnosis of the cause of ketosis is very important for the application of adequate therapy; however the distinction between primary and secondary ketosis is quite complicated. The practitioners should regularly examine the rumen fluid of not only the affected but also of other (healthy) animals, as the duration of DMI depression is mostly unknown. The differentiation of the secondary ketosis developing due to SARA from the primary production ketosis is important not only for the adequate therapy of individual cows but mainly for the herd health management and correct modification of the ration. 


\section{Conclusion}

On the basis of performed analysis we can conclude that subclinical ketosis (increased concentration of $\mathrm{BHB}$ in blood) has important relations to other metabolic disorders, mainly lipid mobilization, liver steatosis, hypocalcaemia and rumen dysfunction. The significant positive correlations were found between BHB and NEFA, AST, GGT, total bilirubin, urea; negative correlations were between BHB and glucose, calcium, magnesium. The relations between ketosis and rumen fermentation are complicated and show high variability. Subclinical ruminal acidosis was found in $23.1 \%$ and $16.7 \%$ of dairy cows with mild $(1.2-2 \mathrm{mmol} / \mathrm{L})$ and high blood BHB concentration ( $>2 \mathrm{mmol} / \mathrm{L}$ ) and simple ruminal indigestion in $16.7 \%$ and $30 \%$, respectively. It is necessary to take into account that ruminal acidosis can be a cause of ketosis in dairy cows. Practitioners should pay close attention to the correct evaluation of rumen fermentation in cows with subclinical ketosis. Only complex and precise diagnostic work allows applying correct and successful therapy for individual animals and adequate measures in herd health management practices.

\section{Acknowledgements}

This research was carried out with the support of the grant 10/2011/FVL of IGA of University of Veterinary and Pharmaceutical Sciences Brno.

\section{References}

A b d e l a N. (2016). Sub-acute ruminal acidosis (SARA) and its consequences in dairy cattle: A review of past and recent research at global prospective. Achievements in the Life Science, 10: 187-196.

A bdelli A., R abo is s on D., Ka id i R., Ibrah i m B., Ka le m A., Ig u e r - O u a d a M. (2017). Elevated non-esterified fatty acid and $\beta$-hydroxybutyrate in transition dairy cows and their association with reproductive performance and disorders: A meta-analysis. Theriogenology, 93: 99-104.

B a ch K.D., H e u w i e s e r W., M c A rt J.A.A. (2016). Technical note: Comparison of 4 electronic handheld meters for diagnosing hyperketonemia in dairy cows. J. Dairy Sci., 99: 9136-9142.

B obe G., Young J.W., B e itz D.C. (2004). Invited review: Pathology, etiology, prevention, and treatment of fatty liver in dairy cows. J. Dairy Sci., 87: 3105-3124.

Chap in al N., Car son M.E., L e B lan c S.J., L e s li e K.E., Godden S., C a pe 1 M., S anto s J.E.P., O v e r t o n M.W., D u f fi e ld T.F. (2012). The association of serum metabolites in the transition period with milk production and early-lactation reproductive performance. J. Dairy Sci., 95: 1301-1309.

D a n fa er A., Teten s V., A gerg a ard N. (1995). Review and an experimental study on the physiological and quantitative aspects of gluconeogenesis in lactating ruminants. Comp. Biochem. Physiol., 111B: 201-210.

D o r e a u M., O 11 i e r A., M a c h l e t - D o r e a u B. (2001). An atypical case of ruminal fermentations leading to ketosis in early lactating cows. Rev. Med. Vet., 152: 301-306.

Duffield T., Lis s e more K., M c B ride B., Les li e K. (2009). Impact of hyperketonemia in early lactation dairy cows on health and production. J. Dairy Sci., 92: 571-580.

En e mark J.M.D. (2008). The monitoring, prevention and treatment of subacute ruminal acidosis (SARA): a review. Vet. J., 176: 32-43.

E n e mark J.M.D., J org e n s e n R.J. (2001). Subclinical rumen acidosis as a cause of reduced appetite in newly calved cows in Denmark: Results of a poll among Danish dairy practitioners. Vet. Quarterly, 23: 206-210.

G o ff J.P. (2008). The monitoring, prevention, and treatment of milk fever and subclinical hypocalcemia in dairy cows. Vet. J., 176: 50-57. 
González F.D., Muiño R., P ereira V., Campos R., B en edito J.L. (2010). Relationship among blood indicators of lipomobilization and hepatic function during early lactation in highyielding dairy cows. J. Vet. Sci., 12: 251-255.

Hofírek B., Ha a D. (2001). Comparative studies of ruminal fluid collected by oral tube or by puncture of the caudoventral ruminal sac. Acta Vet. Brno, 70: 27-33.

Hofirek B., Dvořák R., Něm eček L., D o ležel R., P o s píši 1 Z., et al. (2009). Cattle diseases (in Czech). ČBS, Noviko a.s. (CZ), 1149 pp.

In g v a rts e n K.L. (2006). Feeding- and management-related diseases in the transition cow. Physiological adaptations around calving and strategies to reduce feeding-related diseases. Anim. Feed Sci. Tech., 126: 175-213.

K i m u r a K., R e in ha rd t T.A., G o ff J.P. (2006). Parturition and hypocalcemia blunts calcium signals in immune cells of dairy cattle. J. Dairy Sci., 89: 2588-2595.

K l e e n J.L., C a n n i z z o C. (2012). Incidence, prevalence and impact of SARA in dairy herds. Anim. Feed Sci. Tech., 172: 4-8.

L e a n I.J., B r u s s M.L., B a l d w in R.L., Troutt H.F. (1992). Bovine ketosis: a review. II. Biochemistry and prevention. Vet. Bull., 62: 1-14.

Li P., Li X.B., F u S.X., Wu C.C., Wang X.X., Yu G.J., L ong M., Wang Z., Li u G.W. (2012). Alterations of fatty acid $\beta$-oxidation capability in the liver of ketotic cows. J. Dairy Sci., 95: 1759-1766.

Mc Art J.A.A., Nydam D.V., O etzel G.R., Overton T.R., Os p in a P.A. (2013). Elevated non-esterified fatty acids and $\beta$-hydroxybutyrate and their association with transition dairy cow performance. Vet. J., 198: 560-570.

M c Carthy M.M., Mann S., N y d a m D.V., Overton T.R., M c A r t J.A.A. (2015). Short communication: Concentrations of nonesterified fatty acids and $\beta$-hydroxybutyrate in dairy cows are not well correlated during transition period. J. Dairy Sci., 98: 6284-6290.

O w e n s F.N., S e crist D.S., Hill W.J., Gi 11 D.R. (1998). Acidosis in cattle: A review. J. Anim. Sci., 76: 275-286.

P e chová A., I 11 e k J., P a v la t a L. (2002). Einwirkungen der Lebersteatose auf den Stoffwechsel bei Milchkühen. Wien. Tierärztl. Mschr., 89: 325-332.

Pla izier J.C., Krause D.O., Gozho G.N., M c Bride B.W. (2008). Subacute ruminal acidosis in dairy cows: the physiological causes, incidence and consequences. Vet. J., 176: 21-31.

R a b o is s on D., M o u n i é M., M a i g né E. (2014). Diseases, reproductive performance, and changes in milk production associated with subclinical ketosis in dairy cows: A meta-analysis and review. J. Dairy Sci., 97: 7547-7563.

Re inhardt T.A., Lippolis J.D., M c Cluskey B.J., Goff J.P., Horst R.L. (2011). Prevalence of subclinical hypocalcaemia in dairy herds. Vet. J., 188: 122-124.

R u o ff J., B e r t u l a t S., B u rf e in d O., H e u w i e s e r W. (2016). Associations of $\beta$-hydroxybutyrate, cholesterol, triglycerides and high-density lipoproteins to non-esterified fatty acids pre- and postpartum. J. Dairy Res., 83: 447-452.

Stefanska B., Now a k W., Ko m is a rek J., Taciak M., B ars zcz M., Sk omial J. (2017). Prevalence and consequence of subacute ruminal acidosis in Polish dairy herds. J. Anim. Physiol. Anim. Nutr., 101: 694-702.

Tothova C., N a g y O., K ova c G. (2014). Relationship between some variables of protein profile and indicators of lipomobilization in dairy cows after calving. Archiv Tierzucht., 57: 1-9.

Weng X., Zha o W., Ne ethirajan S., Duffield T. (2015). Microfluidic biosensor for $\beta$ Hydroxybutyrate ( $\beta \mathrm{HBA}$ ) determination of subclinical ketosis diagnosis. J. Nanobiotechnol., 13, http:// dx.doi.org/10.1186/s12951-015-0076-6

Zhang Z., Liu G., Li X., Ga o L., Guo Ch., Wang H., Wang Z. (2010). Evaluation of the change of serum copper and zinc concentrations of dairy cows with subclinical ketosis. Biol. Trace Elem. Res., 138: 8-12.

Received: 9 I 2018

Accepted: 27 VII 2018 